\title{
CORPORATE SOCIAL RESPONSIBILITY IN INTERNATIONAL ECONOMIC LAW PERSPECTIVE
}

\author{
Nyoman Indra Juarsa $^{1)}$ and Yanuarda Yudo Persian ${ }^{2)}$ \\ 1) Post Graduate Student, Faculty of Law, Padjajaran University \\ Email: humbler1992@yahoo.com, nyomanindrajuarsa@yahoo.com \\ 2) Junior lawyer at Dyah Ersita and Partners Law Firm, Jakarta \\ Email: yanuardayudopersian@yahoo.com
}

\begin{abstract}
Multinational Corporation/MNC has a significant role to play in promoting sustainable development and alleviating global poverty. As a subject of International Economic Law, MNC has the rights to take profit from its business activities. In addition, it also has responsibility to protect sustainable environment through CSR program. This paper focuses on what more specific instrument sets CSR in international economic law, and how CSR can be implemented by the MNC. International (public) law has been providing instruments to regulate MNC activities related to CSR, those are: OECD Guidelines, ILO Declaration and UN Global Compact. However, they are only "soft laws" that still require more specific instrument to be implemented. As a continuation of the general rules of public international CSR Instruments, the World Bank Group through the IFC and MIGA sets standard performances that must be met by every corporation that will get finance (IFC) or guarantee (MIGA). Standard Performances are described further in the environmental, health and safety guidelines that are essential for every company to provide protection to stakeholders related to business activities including workers, communities, and environment. As the method of evaluation and enforcement, IFC and MIGA have institution namely Compliance Advisor Ombudsman serving to receive reports from the public, investigate and provide notification to the company activities that negatively affect the society. Ultimately CSR is not only seen as philanthropy (mandatory) but also as guidelines and a code of conduct to be followed by the corporation in carrying out any business.
\end{abstract}

Key words: mandatory norm, obligatory norm, CSR

\section{INTRODUCTION}

Multinational Corporation/MNC has a significant role in promoting sustainable development and alleviating global poverty. MNC enters to country through direct or indirect investment. MNC develops very rapidly along with economic liberalization system that allows big enterprises to conduct business expansion across the country freely.

MNC is defined as an entity that crosses national boundaries. MNC has special characteristics, which is usually comprises of interconnected companies or 
other entities established in more than one country and they may coordinate their operations in various ways. While one or more of these entities may be able to exercise a significant influence over the activities of others, their degree of autonomy within the enterprise may vary widely from one multinational enterprise to another. Ownership may be private, state or mixed ${ }^{1}$.

Within the scope of the civil law, MNC is categorized as recht persoon, which recognized as a subject of law by having legal personality. Legal personality includes abilities and accessibility before the law, which set forth in the deed. As a civil entity MNC position cannot be doubted. It becomes a strong, structured and crossborder entity (in the context of the owners and management). However, the legal position of MNC as subject of international law $^{2}$ is still debatable.

Some argument puts MNC as a subject of international law and considers that the MNC is the development of the individual term. The subject of international law is divided into two main categories,

\footnotetext{
${ }^{1}$ OECD Guidelines, Part I, p. 12

$\mid{ }^{2}$ In this context, the terms of International Law, refers to International Public Law. It is based on the command agreement in using International Law term in public aspect, not in private aspect. See: Mochtar Kusumaatmadja, Pengantar Hukum Internasional (Introduction of International Law), Bandung: Alumni, 2010, p. 1
}

State and non-State. The state is a political and legal entity recognized by the international community ${ }^{3}$. Non-state subject includes International Organizations, Belligerent and Individual. The use of individual terms can be understood also as a group or entities consist of individual subject (natuurlijke persoon). Therefore, granting the rights and obligations as well as the treatment of $\mathrm{MNC}$ in front of international law is equated with the individual treatment.

In the other hand, the opposite argument states that MNC does not have rights and obligations under international law; it is only subjects of national law and transnational law ${ }^{4}$. Wolfgang Friedman stated that the expansion of subject international law is subversive and cannot be maintained. It will even negate the separation between public and private sector in national law. Furthermore, Wolfgang offers that MNC needs to have legal status as well as international organizations, but in limited granting. The MNCs subjectivity will be limited and temporary (ad hoc) as far

\footnotetext{
${ }^{3}$ Montevideo Convention Rights and Duties of States 1933. Article 1: The state as a person of international law should possess the following qualifications: (a) a permanent population; (b) a defined territory; (c) government; and (d) capacity to enter into relations with the other states.

${ }^{4}$ Antonio Cassese, International law in Devided World, 1986, p. 78-79
} 
as their activities regulated by the norms of Public International Law ${ }^{5}$.

In addition, there are two concerns of MNC recognition as subjects of international law. First, foreign corporations will be easier to intervene in political and economic policy of host country. Second, foreign corporations can demand excessive diplomatic protection to the home state, especially if other foreigners dominate the corporate stock ${ }^{6}$.

From the theoretical debates above, it can be briefly concluded that the corporation is considered to have the status of a subject of international law in limited meaning. The status is different from the other subjects of international law, such as states and international organizations. The limited nature lies in a field that is run by the MNC, that is the economy. Asif H. Qureshi argues that the MNC has a legal personality in the international economic law as well as the individual. It has a personality which entitles to operate on the international plane. The ranges of entitlement are varied and depend on the kind of the subject involved. Thus entitlements involve for example: being able to enter into international

\footnotetext{
${ }^{5}$ Wolfgang Friedman in Antonio cassese, Ibid, p. 103

${ }^{6}$ Andrew Clapham, Human Rights Obligations of Non-State Actor, New York: Oxford University Press, 2006, p. 78
}

economic agreements; being able to enforce international economic agreements; becoming beneficiaries of international economic agreements; and being able to participate in dispute settlement mechanisms involving economic rights. ${ }^{7}$

The subject of international law is an entity capable of possessing international rights and duties and having the capacity to maintain its rights by bringing international claims $^{8}$. As a subject of international economic law, $\mathrm{MNC}$ has the legal rights and obligations set out in international economic law. The major rights of MNC include running their business safely and can enjoy the benefits of its business. The primary obligation of MNC is keeping the "good relationship" with the company's stakeholders. Based on the Stakeholder Theory, there are two types of stakeholders, namely: primary stakeholders (employees/workers, consumers, investors, and suppliers), and additional stakeholders outside the main stakeholders. ${ }^{9}$

\footnotetext{
${ }^{7}$ Asif H. Qureshi, International Economic Law, Manchester: Sweet and Maxwell, 1999, h. 27 ${ }^{8}$ Ian Brownlee, Principles of Public International Law, New York: Oxford University Press, 2008, p. 57

${ }^{9}$ A. B. Carollin Ilias Bantekas, Corporate Social Responsibility in International Law, Boston University International Law Journal, Volume 22:309, 2004, p. 311
} 
The MNCs responsibility can be done by implementing Corporate Social Responsibility/CSR. There are probably as many understandings of corporate social responsibility as there are stakeholders involved in discussions on the issue. At its most basic level, corporate responsibility is concerned with the relationships that a company maintains with its shareholders, clients, suppliers, creditors and employees, as well as with the communities in which it operates $^{10}$. Essentially, CSR recognizes that corporations are not only responsible to their shareholders, but owe or should owe, particular duties to person or communities directly or indirectly effected their operations.

From very broad CSR objectives, which include all stakeholders, CSR can also be implemented in various forms. The implementation of CSR refers to three things: human rights, labor rights, environmental rights and sustainable development, those are called as the core of CSR. To run the CSR, MNC makes voluntary self-regulation tailored to the needs of corporations and the environment. However, in implementing CSR, MNCs

\footnotetext{
${ }^{10}$ United Nation, Chapter XX, p. 251 http://www.un.org/esa/socdev/rwss/docs/2001/20\%2 0Corporate\%20social\%20responsibilities.pdf
}

should be in line with the rule of law and code of conduct generally.

CSR has voluntary characteristic which applications are based on the abilities and capabilities of the MNC in question. CSR can be seen as a form of responsibility that the implementation can be forced. Some international legal norms have given signal the MNC obligation to implement CSR, such as the OECD Guidelines, the ILO Declaration and the UN Global Compact. However, they are only "soft laws" that require still more specific instrument to be implemented.

As a continuation of the general rules of public international CSR Instruments, the World Bank Group through the International Finance Cooperation/IFC and Multilateral Investment Guarantee Agency/MIGA sets standard performances that must be met by every corporation that will get finance (IFC) or guarantee (MIGA). Standard Performances are described further in the environmental, health and safety guidelines that are essential for every company to provide protection to stakeholders related to business activities including workers, communities, and environment.

This paper aims to explore the range of particular CSR principles under IFC and MIGA regulations and the model of 
implementations, enforcement, and monitoring. Finally, it examines the viability and success of such measures and the extralegal parameters of $\mathrm{MNC}$ adherence to norms that may be seen as irrelevant or nonbinding because of their voluntary character.

\section{METHODE OF RESEARCH}

This study uses normative juridical method, with the starting point of research on international economic law instruments or legal instrument regulating CSR. The approach that is used in this study research is conceptual approach, to understand the concepts of CSR, as well as deal with the concept CSR as voluntary and mandatory norm.

Legal materials used are all the rules relating to CSR in international economic law. The Materials are then analyzed descriptively with the deduction method. With this technique, researchers analyze the rules, doctrines and theories about CSR, then pulled more specifically on the implementation model of CSR.

\section{RESULT AND DISCUSSION}

\section{A. Sources of Corporate Social Responsibility}

CSR is related to corporation behavior in maintaining relationship with the stakeholder. Originally, CSR only considered as voluntary norm ${ }^{11}$, but it develops into more concrete responsible form since the growing awareness of international community to increase the voluntary status. Various international organizations have given attention to the behavior of transnational corporations through various guidelines, code of conduct, resolutions, declarations, principles, reports and other documents. Various instruments contain arrangements that are intended to control the behavior of transnational corporations. Those instruments lay the responsibility of corporation in various actions. We identify two forms of legal source of CSR; those are the general rule contained in international law (public) and more detailed rules contained in the IFC and MIGA. Each will be examined in turn.

\section{Public International CSR Instruments}

The first multilateral effort to produce MNC's code of conduct or guidelines has been initiated by ECOSOC. ECOSOC established The Commission on

\footnotetext{
${ }^{11}$ The 2001 European Commission Green Paper on CSR defines this Responsibility as "a concept whereby companies decide voluntary to contribute to a better society and a clearer environment". See Promoting a European Framework for Corporate Social Responsibility: Green Paper. http://europa.eu.int/comm/employment_social/socdial/csr/greenpaper_en.pdf (hereinafter Green Paper)
} 
Transnational Corporation (UNCTC) that produced The Draft UN Code of Conduct on Transnational Corporation, OECD Guidelines for Multinational Corporation, UN Global Compact, and Human Rights Principles and Responsibilities for Transnational Corporation and Other Business Enterprises. The most public international CSR instruments are the OECD Guidelines, the UN Global Compact and the 1998 ILO Declaration on Fundamental Principles and Rights at Work.Organization for Economic Cooperation and Development (OECD) Guidelines for Multinational Enterprises

OECD is an organization established in 1960. This organization was established in order as a reaction to transnational crime acts that illegal and not ethically in how to make recommendations or guidelines that addressed to a transnational corporation.

OECD Guidelines adopted first in 1976 and amended periodically, last amendment is in 2011. The Guidelines taken into legal by 30 OECD's state parties and accepted by 8 non-state parties ${ }^{12}$, thus, OECD Guidelines is addressed to all corporations that operates or derive from the 38 state parties. However, OECD Guidelines

\footnotetext{
${ }^{12}$ Www.oecd.org
}

is also can be prevail in other country outside the state parties.

The guidelines implementation is monitored by flexible complaint mechanisms, in contrast to the litigation mechanism or any other legal complaints. Unlike other "soft law" that is addressed by particular bodies of international organization to their member state, the OECD guidelines are recommendations addressed by governments to MNC. Although they are not legally binding on MNC, OECD member states have agreed to adhere to the guidelines and encourage their companies to observe them wherever they operate $^{13}$. OECD Secretary General clearly states that the purpose of OECD is to provide guidelines for the government on setting standards of good corporate conduct.

In general policy, OECD conducts enterprises should take established policies in the countries in which they operate fully into account, and consider the views of other stakeholders. In this regard: ${ }^{14}$

Enterprises should:

1) Contribute to economic, environmental and social progress with a view to achieving sustainable development.

\footnotetext{
${ }^{13}$ See OECD Guidelines, Foreword, Paragraph 1

${ }^{14}$ General Policies of OECD Guidelines for Multinational Enterprises 2011,
} 
2) Respect the internationally

recognized human rights of those affected by their activities.

3) Encourage local capacity building through close cooperation with the local community, including business interests, as well as developing the enterprise's activities in domestic and foreign markets, consistent with the need for sound commercial practice.

4) Encourage human capital formation, particularly by creating employment opportunities and facilitating training opportunities for employees.

5) Refrain from seeking or accepting exemptions not contemplated in the statutory or regulatory framework related to human rights, environmental, health, safety, labor, taxation, financial incentives, or other issues.

6) Support and uphold good corporate governance principles and develop and apply good corporate governance practices, including throughout enterprise groups.

7) Develop and apply effective self-regulatory practices and management systems that foster a relationship of confidence and mutual trust between enterprises and the societies in which they operate.

8) Promote awareness of and compliance by workers employed by multinational enterprises with respect to company policies through appropriate

dissemination of these policies, including through training programs.

9) Refrain from discriminatory or disciplinary action against workers who make bona fide reports to management or, as appropriate, to the competent public authorities, on practices that contravene the law, the Guidelines or the enterprise's policies.

10) Carry out risk-based due diligence, for example by incorporating it into their enterprise risk management systems, to identify, prevent and mitigate actual and potential adverse impacts as described in paragraphs 11 and 12, and account for how these impacts are addressed. The nature and extent of due diligence depend on the circumstances of a particular situation. 
11) Avoid causing or contributing to adverse impacts on matters covered by the Guidelines, through their own activities, and address such impacts when they occur.

12) Seek to prevent or mitigate an adverse impact where they have not contributed to that impact, when the impact is nevertheless directly linked to their operations, products or services by a business relationship. This is not intended to shift responsibility from the entity causing an adverse impact to the enterprise with which it has a business relationship.

13) In addition to addressing adverse impacts in relation to matters covered by the Guidelines, encourage, where practicable, business partners, including suppliers and sub-contractors, to apply principles of responsible business conduct compatible with the Guidelines.

14) Engage with relevant stakeholders in order to provide meaningful opportunities for their views to be taken into account in relation to planning and decision making for projects or other activities that may significantly impact local communities.

15) Abstain from any improper involvement in local political activities.

Enterprises are encouraged to:

1) Support, as appropriate to their circumstances, cooperative efforts in the appropriate forum to promote Internet Freedom through respect of freedom of expression, assembly and association online.

2) Engage in or support, where appropriate, private or multistakeholder initiatives and social dialogue on responsible supply chain management while ensuring that these initiatives take due account of their social and economic effects on developing countries and of existing internationally recognized standards.

The Guidelines recommends that enterprises apply good corporate governance practices drawn from the OECD Principles of Corporate Governance. The Principles call for the protection and facilitation of the exercise of shareholder rights, including the equitable treatment of shareholders. Enterprise should recognize the rights of stakeholders established by law or through mutual agreements and encourage active co- 
operation with stakeholders in creating wealth, jobs, and the sustainability of financially sound enterprises. ${ }^{15}$

\section{a) United Nation Global Compact}

In the World Economic Forum held in January 1999 in Davos, Switzerland, UN Secretary-General recommended the leader of the business world to formulate and issue the Global Compact, both with regard to the practice of the corporation as individual or by developing public policy. Global Compact contains 10 principles that must be adhered to by the corporation.

The UN Global Compact's ten principles in the areas of human rights, labor, the environment and anti-corruption enjoy universal consensus and are derived from: The Universal Declaration of Human Rights; The International Labor Organization's Declaration on Fundamental Principles and Rights at Work; The Rio Declaration on Environment and Development; The United Nations Convention Against Corruption. The UN Global Compact asks companies to embrace, support and enact, within their sphere of influence, a set of core values in the areas of

${ }^{15}$ Commentary on General Policies, OECG Guidelines 2011 human rights, labor standards, the environment and anti-corruption: ${ }^{16}$

a. Human Rights

Principle 1: Businesses should support and respect the protection of internationally proclaimed human rights; and

Principle 2: make sure that they are not complicit in human rights abuses.

b. Labor

Principle 3: Businesses should uphold the freedom of association and the effective recognition of the right to collective bargaining;

Principle 4: the elimination of all forms of forced and compulsory labor;

Principle 5: the effective abolition of child labor; and

Principle 6: the elimination of discrimination in respect of employment and occupation.

c. Environment

Principle 7: Businesses should support a precautionary approach to environmental challenges;

Principle 8: undertake initiatives to promote greater environmental responsibility; and

Principle 9: encourage the development and diffusion of environmentally friendly technologies.

d. Anti-Corruption

Principle 10: Businesses should work against corruption in all its forms, including extortion and bribery.

The principles mentioned above directly leads to points CSR. UN Global Compact describes corporate responsibility

\footnotetext{
16 The Ten Principles of UN Global Compact, www.unglobalcompact.org
} 
in running the business, including social responsibility. However, as with OECD guidelines, the principles are only as voluntary norm submitted to the respective enterprise policies.

\section{b) ILO Declaration}

Adopted in 1998, the ILO Declaration on Fundamental Principles and Rights at Work is an expression of commitment by governments, employers' and workers' organizations to uphold basic human values that are vital to our social and economic lives. These principles and rights are:

1) freedom of association and the effective recognition of the right to collective bargaining;

2) The elimination of all forms of forced or compulsory labor;

3) The effective abolition of child labor;

4) The elimination of discrimination in respect of employment and occupation.

A further recognition of the importance of these principles and rights has been their incorporation into the Global Compact, an initiative of the United Nations Secretary General. Like the ILO
Declaration, the Global Compact is a platform designed to promote learning and good practices of businesses, based on universal principles.

Despite all the instrument has been set on CSR, the voluntary character is still strongly attached. This is evident from the lack of implementation and enforcement mechanisms of CSR by MNCs. However, they are only "soft laws" that require still more the specific instrument to be implemented.

\section{International Economic Law}

At the bottom, IEL's legal sources are not really has differences with Public International Law. But, there are additional legal sources which are code of conduct and guidelines. IEL in broader meaning includes the economic relationship that public in character (policy) and private (economic activities practice). IEL emphasized its study to the world economic institutions that known as the three pillars of world economic, which are WBG, IMF and $\mathrm{WTO}_{2}$ that has influence the world economic system. Thereby, is necessary to concern the IEL legal base that relevance with those economic institutions that specifically regulates the CSR implementation by MNC. 
As a continuation of the general rules of public international CSR Instruments, the World Bank Group through the IFC and MIGA sets standard performances that must be met by every corporation that will get finance (IFC) or guarantee (MIGA). Standard Performances are described further in the environmental, health and safety guidelines that essential for every company to provide protection to stakeholders related to business activities including workers, communities, and environment.

a) IFC's Policy on Social and Environmental Sustainability

IFC, a member of the World Bank group, is the largest global development institution focused on the private sector in developing countries. IFC creates opportunity for people to escape poverty and improve their lives. It helps developing countries achieve sustainable growth by financing investment, providing advisory services to businesses and governments, and mobilizing capital in the international financial markets ${ }^{17}$. In giving financial assistance, IFC sets standard performances that must be met by every client (corporation) in sustainability framework

\footnotetext{
${ }^{17}$ IFC overview, www.ifc.org/aboutifc
}

through IFC's Policy on Social and Environmental Sustainability ${ }^{18}$.

IFC's Sustainability Framework articulates the corporation's strategic commitment to sustainable development, and is an integral part of IFC's approach to risk management. The Sustainability Framework comprises IFC's Policy and Performance Standards on Environmental and Social Sustainability, and IFC's Access to Information Policy. The Policy on Environmental and Social Sustainability describes IFC's commitments, roles, and responsibilities related to environmental and social sustainability.

The Performance Standards are directed towards clients, providing guidance on how to identify risks and impacts, and are designed to help avoid, mitigate, and manage risks and impacts as a way of doing business in a sustainable way, including stakeholder engagement and disclosure obligations of the client in relation to project-level activities. In the case of its direct investments (including project and corporate finance provided through financial intermediaries). IFC requires its clients to apply the Performance Standards to manage environmental and social- risks and impacts,

\footnotetext{
${ }^{18}$ Originally adopted in 2006 and the latest update effective on 1st January 2012, www.ifc.org/sustainabilityframework
} 
so that development opportunities are enhanced. IFC uses the Sustainability Framework along with other strategies, policies, and initiatives to direct the business activities of the Corporation in order to achieve its overall development objectives.

The Performance Standards may also be applied by other financial institutions.

The Performance Standards consist of the following:

\section{Performance Standard 1:} Assessment and Management of Environmental and Social Risks and Impacts

Underscores the importance of identifying $E \& S$ risks and impacts, and managing E\&S performance throughout the life of a project.

Performance Standard 2: Labor and Working Conditions

Recognizes that the pursuit of economic growth through employment creation and income generation should be balanced with protection of basic rights for workers.

\section{Performance Standard 3:} Resource Efficiency and Pollution Prevention

Recognizes that increased industrial activity and urbanization often generate higher levels of air, water, and land pollution, and that there are efficiency opportunities.
Performance Standard 4: Community Health, Safety, and Security

Recognizes that projects can bring benefits to communities, but can also increase potential exposure to risks and impacts from incidents, structural failures, and hazardous materials.

Performance Standard 5: Land Acquisition and Involuntary Resettlement

Applies to physical or economic displacement resulting from land transactions such as expropriation or negotiated settlements.

Performance Standard 6: Biodiversity Management and Sustainable Management of Living Natural Resources

Promotes the protection of biodiversity and the sustainable management and use of natural resources.

Performance Standard 7: Indigenous Peoples

Aims to ensure that the development process fosters full respect for Indigenous Peoples.

Performance Standard 8: Cultural Heritage

Aims to protect cultural heritage from adverse impacts of project activities and support its preservation.

Performance Standard 1 establishes the importance of (i) integrated assessment to identify the environmental and social 
impacts, risks, and opportunities of projects;

(ii) effective community engagement through disclosure of project-related information and consultation with local communities on matters that directly affect them; and (iii) client's management of environmental and social performance throughout the life of project. Performance Standards 2 through 8 establish objectives and requirements to avoid, minimize, and where residual impacts remain, to compensate/offset for risks and impacts to workers, effected communities, and the environment. While all relevant environmental and social risks and potential impacts should be considered as part of the assessment. Performance Standards 2 through 8 describe potential environmental and social risks and impacts that require particular attention. Where environmental or social risks and impacts are identified, the client is required to manage them through its Environmental and Social Management System (ESMS) consistent with Performance Standard 1.

b. MIGA's Policy on Social and Environmental Sustainability

MIGA is a member of the World Bank Group. Its mission is to promote foreign direct investment (FDI) into developing countries to help support economic growth, reduce poverty, and improve people's lives. ${ }^{19}$ MIGA's operational strategy plays to its foremost strength in the marketplace-attracting investors and private insurers into difficult operating environments.

As a multilateral development agency, MIGA only supports investments that are developmentally sound and meet high social and environmental standards. MIGA applies a comprehensive set of social and environmental performance standards to all projects and offers extensive expertise in working with investors to ensure compliance to these standards.

Through MIGA's Policy on Social and Environmental Sustainability, MIGA puts into practice its commitment to social and environmental sustainability. This policy applies to all investment guarantees for which Definitive Applications were received after October 2007.

The Performance Standards consist of the following: 20

Performance Standard 1:

Social and Environmental

Assessment and

Management System

Performance Standard 2:

Labor and Working Conditions

\footnotetext{
${ }^{19}$ MIGA Overview, www.miga.org

${ }^{20}$ Policy on Social and Environmental Sustainability, Section 1: Purpose of Policy
} 
Performance Standard 3:

Pollution Prevention and

Abatement

Performance Standard 4:

Community Health, Safety, and Security

Performance Standard 5:

Land Acquisition and Involuntary Resettlement

Performance Standard 6:

Biodiversity Conservation

and Sustainable Natural

Resource Management

Performance Standard 7:

Indigenous Peoples

Performance Standard 8:

Cultural Heritage

These Performance Standards are essential documents to help MIGA and its clients manage and improve their social and environment performance through an outcomes-based approach. The desired outcomes are described in the objectives of each Performance Standard, followed by specific requirements to help clients achieve these outcomes through means that are appropriate to the nature and scale of the project and commensurate with the level of social and environmental risks (likelihood of harm) and impacts. Central to these requirements is a consistent approach to avoid adverse impacts on workers, communities, and the environment, or if avoidance is not possible, to reduce, mitigate, or compensate for the impacts, as appropriate. The Performance Standards also provide a solid base from which clients may increase the sustainability of their business operations.

Central to MIGA's development mission are its efforts to carry out its support to projects and advisory services in a manner that "do no harm" to people or the environment. Negative impacts should be avoided where possible, and if these impacts are unavoidable, they should be reduced, mitigated or compensated for appropriately. In particular, MIGA is committed to ensuring that the costs of economic development do not fall disproportionately on those who are poor or vulnerable, that the environment is not degraded in the process, and that natural resources are managed efficiently and sustainably. MIGA believes the client's regular engagement with local communities about matters that directly affect them plays an important role in avoiding or reducing harm to people and the environment. MIGA also recognizes that the roles and responsibilities of the private sector in respecting human rights are emerging as an important aspect of corporate social responsibility. The Performance Standards help private sector clients address environmental and social risks and opportunities, consistent with these emerging roles and responsibilities. 


\section{B. Implementation of CSR in IFC and MIGA Guidelines}

Both IFC and MIFA have CSR implementation and evaluation model to a corporation whom they help. Both have same identical characteristic which is helping private sector (MNC) in accordance to investment development, they also applied the same policy in the application on rules and evaluation models through their client. Generally, the enforcement on CSR can be seen on two process, which are, before the business activities run - as preventive action - and when the MNC's business activities run - as repressive and evaluation.

\section{a. Preventive Action}

This effort concerned in the standard performances rules that have to be fulfilled by the client company of IFC and MIGA. From IFC and MIGA guidelines above, can be seen that there are steps that have to be fulfilled by the company to reach the IFC and MIGA's support, which are:

Step 1: The application of cooperation proposal by the client to IFC and MIGA.

Step 2: IFC and MIGA through Environmental and Social (E\&S) Team assess the proposal relevance with the standard performance and the other documents that related with the distribution aid rules.
Step 3: Negotiation and commitment Step 4: Signature

The E\&S's team assessment step is very important, to determine the client's CSR program is adequate with the standard performance admitted, specially to program that has high rate of social and environmental risk, for example: mining and plantation. If E\&S team concluded that the client is improper, thus the aid will not be given, or the client have to change the proposal and commitment to carry out the sustainable environment, development and has CSR program to the relevant around society.

b. Repressive Action/ Evaluation

As monitoring and evaluation mechanism, the both of IFC and MIFA established Compliance Advisor Ombudsman/CAO. CAO is an independent organ in order to projects mechanism that supported by the World Bank Group's private sector - IFC and MIGA. CAO responsible directly to WBG's President. CAO works with all parties that concerned which took part in the projects to seek out the real solution in increasing social and environmental result in the field.

Each individuals, groups, society, or any party could file complaint to $\mathrm{CAO}$ if they are believes that they, or maybe, 
influenced by the agency or organization. The complaints shall be written submitted and could be written in any language.

Complaints may relate to any aspects of the planning, implementation, or impact of IFC/MIGA projects, including but not limited to: 1) Processes followed in preparation of a project; 2) The adequacy of measures for the mitigation of social and environmental impacts of the project; 3) Arrangements for involvement of affected communities, minorities, and vulnerable groups in the project; 4) The manner in which the project is implemented.

$\mathrm{CAO}$ has simply 3 rules criteria to make up the complaints through from the examination:

1) The complaints related to IFC and MIGA's projects (including a project in consideration)

2) The complaints related to social and/or environmental issues that related to the projects.

3) The complaint's party shall believe that they, or maybe, influenced by the social and/or environmental issues risen.

Despitefully, CAO cannot take complaints that did not meet the 3 criteria.

1) When the complaints related to other financial organs (like, not came from
IFC and MIGA), CAO insist to direct the complaint party to the exact office.

2) The complaints with deception and corruption notion will be transferred to the World Bank Institutional Integrity Office. CAO also could not revise complaints which related to IFC and MIGA's decisions.

3) CAO denied complaints that wicked, trivial, or submitted in order to achieve competitive advantage.

The following steps will normally be followed in response to a complaint that is received:

Step 1 Acknowledgement of receipt. Step 2 Assessment of eligibility and decision whether to proceed (no more than 15 working days).

Step 3 Assessment of potential for achieving resolution of the complaint (no more than 120 working days).

Step 4 If CAO ombudsman process continous, then implementation of MOU through facilitation/mediation, joint-fact-finding, or other agreed resolution process, leading to a settlement agreement or other mutually agreed and appropriate goal.

Step 5 Monitoring and follow-up.

Step 6 Conclusion.

$\mathrm{CAO}$ will inform the public complaint acceptance (who submits the complaints) in complaint's language version. In 15 workday (complaints and documents translation time needed is not 
included), CAO will informs the complaint party that the complaints is proper to be examine further. When it is proper, the complaint party would receive information that described how $\mathrm{CAO}$ will cooperates to help settle the issues, and CAO's specialist will contacts the complaint party personally.

CAO's Ombudsman conducted an examination to the situation, and helps the parties in determining best alternatives to dealing the complaints. Ombudsman does not make a justification in benefits of the complaints and does not determine solutions or seeks the fault. Our specialist will work together with the parties to identify the alternative approaches and strategies to deal with the issue. It involves collective fact finding, facilitating discussion between the authorized parties, mediating the disputes, or setting up a dialogue forum or collective monitoring program. A CAO's specialist is given Alternative Dispute Resolution (ADR) training with expertise in examining conflicts, providing mediation, and giving multiparty facilitation. They work with independent mediators that have specific reputation suitable with nation and expert in facilitation and consensus in project's range.

Although the CAO is not a judge, court, or the police, there are influential ways in which it can define issues to be addressed in a complaint, make creative and practical proposals for settling an issue, and encourage parties to engage in dialogue. Although the CAO cannot force external entities to change their behavior or abandon existing practices, it can call on the leverage of the IFC and MIGA in disputed parties to adopt recommendations. It is important that complainants should have realistic expectations about what the $\mathrm{CAO}$ can deliver in response to a complaint and that organization which supports complainants explains fully the opportunities opened up by $\mathrm{CAO}$ action and the limits on such action.

Report Case in Indonesia:

CAO Ombudsman conducted an assessment of the issues raised in the complaint and encouraged Wilmar and community members to agree to a dialogue process to help resolve the conflict. A moratorium on further land clearance was announced by Wilmar Group, and the CAO team worked with the communities and Wilmar to build capacity for representation and negotiation. A settlement agreement was announced in late 2008 which contained the following provisions:

- Agreement for community access and use of land that had not been converted to plantations; 
- Compensation for households for appropriation of land;

- Enhanced community investment funds for collective benefits and access to development opportunities for the broader community.

A joint Monitoring and Evaluation (M\&E) team has been established to ensure implementation of these agreements. Questions relating to IFC's due diligence were transferred to CAO Compliance for appraisal. In September 2008, based on the findings of the appraisal, the CAO determined that an audit of IFC was merited to examine whether IFC had complied with its standards and procedures. The CAO released its audit report in August 2009, together with IFC's official response. The audit concluded that IFC had failed to apply its own standards, and its actions were counterproductive to its mission, mandate, and commitment to sustainable development. With regard to IFC's Wilmar Group investments, the CAO found that IFC applied a de minimis approach toward assessing each project's supply chain, and that commercial pressures were allowed to prevail and overly influence the categorization of the project, as well as the scope and scale of IFC's environmental and social due diligence.
IFC acknowledged the shortcomings identified by $\mathrm{CAO}$ in its official response, and communicated an action plan to CAO on how to address them. As part of the action plan, IFC committed to develop a comprehensive strategy for oil palm investments, with specific focus on Indonesia. In September and October 2009, the World Bank Group President instructed IFC and the World Bank Group to suspend financing of oil palm projects until such a strategy had been developed.

Subsequently, in March 2010, IFC embarked on a global consultation to inform its strategy and its future involvement in the oil palm sector. IFC also immediately changed its procedure for processing single commodity trade finance, embarked on reassessing its exposure in Indonesian oil palm sector, and committed to report back to CAO on a quarterly basis on progress to address the shortcomings identified by the CAO audit.

\section{IV.CONCLUSION}

As has been explained before, that there is a displacement concerning to CSR's position understanding. CSR is no longer appreciable as a clean voluntary that cannot be insisted its implementation. It is supported with numbers of international law 
instruments that regulates the MNC's activities related with CSR which is human right fulfillment, labor rights, environmental rights and sustainable development.

As part of international law organ, IFC and MIGA through CAO endeavour to conduct related CSR implementation monitoring. With the existence of this organ, MNC is expected to improve its business environment indifferent. In the end, a good communication between $\mathrm{MNC}$ and the society will bring a good impact to economic and welfare development.

\section{REFERENCES}

\section{Book and Journal}

Mochtar Kusumaatmadja, Pengantar

Hukum Internasional (Introduction of International Law), Bandung:

Alumni, 2010

Antonio Cassese, International law in

Devided World, 1986

Andrew Clapham, Human Rights

Obligations of Non-State Actor, New

York: Oxford University Press, 2006

Qureshi Asif H. International Economic

Law, Manchester: Sweet and

Maxwell, 1999

Brownlee Ian, Principles of Public

International Law, New York:

Oxford University Press, 2008

Ilias Bantekas, Corporate Social

Responsibility in International Law, Boston University International Law Journal, Volume 22:309, 2004

\section{Convention and Online Article}

Montevideo Convention Rights and Duties of States 1933.
United Nation, Chapter XX http://www.un.org/esa/socdev/rwss/do cs/2001/20\%20Corporate\%20social\%2 Oresponsibilities.pdf

Green Paper. http://europa.eu.int/comm/employment _social/soc-dial/csr/greenpaper_en.pdf (hereinaftergreenpaper)

OECD Guidelines, www.oecd.org

UN Global Compact, www.unglobalcompact.org

www.ifc.org/aboutifc

www.miga.org 